\title{
Improving The Competency of Automotive Vocational Teachers with Partnership-Based Training Model (PBK)
}

\author{
Bambang Sudarsono ${ }^{1(*)}$, Budi Santosa ${ }^{2}$, Herminarto Sofyan ${ }^{3}$ \\ ${ }^{1,2}$ Department of Automotive Technology Vocational Education, Universitas Ahmad \\ Dahlan, Yogyakarta, Indonesia \\ ${ }^{3}$ Post Graduate Program Universitas Negeri Yogyakarta, Indonesia
}

\section{Received: November 25, 2020 \\ Revised: January 20, 2021 \\ Accepted: January 20, 2021}

\begin{abstract}
Entering the XXI Century, Industrial Revolution 4.0, and Society 5.0. Improving the quality of human resources is a top priority in meeting the demands of the workforce and the automotive industry. Produce the competencies needed by automotive vocational teachers who master these competencies and are by the needs of the industrial world. This research is designed to produce a partnership-based training model that can be applied and can improve the competence of automotive teachers according to the needs of the automotive industry. This development research consists of two stages, namely the development and validation stages involving vocational education experts, automotive vocational teachers, and industrial practitioners in interviews, Focus Group Discussion activities, and filling out questionnaires. The research subjects were 72 automotive vocational school teachers in Central Java and West Java. The application of this model was carried out in three national automotive industries (the sole agent of the brand holders). The partnership-based training model consists of 6 stages: (1) Information and Communication Learning Activities; (2) Facilitation; (3) Assistance; (4) Monitoring; (5) Process Evaluation and (6) Results in Evaluation. A partnership-based training model can be applied and has received a very good response from automotive participants/ teachers. Based on the questionnaire responses, participants / automotive vocational teachers strongly agree that partnership-based training is applied in the training program. While the competency aspects of attitudes, knowledge, and work skills were achieved with $80 \%$ of participants achieving good criteria.

Keywords: Competency Improvement, Partnership Based Training, Automotive Vocational School Teachers
\end{abstract}

(*) Corresponding Author: $\quad$ bambang.sudarsono@pvto.uad.ac.id

How to Cite: Sudarsono, B., Santosa, B., \& Sofyan, H. (2020). Improving the competency of automotive vocational teachers with partnership-based training model (PBK). Jurnal Teknologi Pendidikan, 22 (3): 200208. http://dx.doi.org/10.21009/jtp.v22i3.18690

\section{INTRODUCTION}

The improvement of teacher competence in the implementation of vocational education continues to be carried out by vocational education managers to obtain quality graduates following the demands of the job market (Hrmo et al., 2016; Suartini, 2019). Vocational education institutions as a provider of prospective workers must be able to utilize resources and network of resources in partnership with outside parties effectively (Audu et al., 2013). The challenges of the world of work demand higher work competencies as technology advances and the dynamics of workplace needs. Challenges in the world of work require vocational education institutions to be able to anticipate and face changes that occur by utilizing various existing capabilities. 
Partnership in the implementation of vocational education between educational institutions and industry/world of work is the main character of vocational education in the process of adapting to the development of the industrial world/work (Fitriana \& Sugiyono, 2019; Muslim, 2019). Therefore, a culture of innovation and quality development of education involves management, professionals (teachers/instructors), and all community institutions including stakeholders to give birth to new ideas in the implementation of vocational education.

Vocational education until now has problems related to the quality of teachers. There are no exceptions for automotive vocational high school (SMK) teachers. SMK Automotive teachers are tasked with equipping learners with skills, knowledge, and attitudes in skills tailored to the automotive field. The purpose of automotive vocational school teachers is to equip students with skills, knowledge, and attitudes to be competent in (a) Automotive motor maintenance and repair; (b) Maintenance and repair of automotive power transfer systems; (c) Maintenance and repair of automotive chassis; (d) Maintenance and repair of automotive electrical systems; and (e) Maintenance and repair of automotive air conditioning systems (Nurtanto et al., 2020).

Some professional studies concluded that in teaching, automotive vocational teachers are still lacking competence. Whereas automotive vocational school teachers must meet the requirements, among others mastery of competency skills and have basic competencies in the automotive field (Mustapha et al., 2016; Mahendra et al., 2019). To achieve the prerequisites of competent automotive vocational teachers, automotive industry support is expected to help in the process of forming ready and competent educators (Iskandar et al., 2020). Teachers of automotive vocational schools as LPTK products still have many limitations in the knowledge of the latest technology. Automotive vocational school teachers are less able to keep up with the advances in science and technology in the automotive industry (Supriyadi et al., 2020). Besides, SMK automotive teachers still tend to be oriented towards school learning, and less focused on achieving competencies according to the needs of the world of work. (Grosch, 2017). To realize SMK automotive teachers who are following the conditions of the world of work and industry, training is required with scientific coverage, facilities, or infrastructure tailored to the automotive industry (Sudira \& Saputro, 2019; Sutijono, 2016; Ismail et al., 2018).

Partnership-based training model (PBK) is a training model that utilizes the world of work/industry ( $\mathrm{Du} / \mathrm{Di})$ to shape the experience and knowledge gained in the workplace to contribute to the development of learning activities. The learning experience in the industry is applied, enhanced, expanded in school learning. The PBK model forms SMK Automotive teachers in attitudes, knowledge, skills, insights, behaviors, habits, and learning experiences and activities according to the world of work. (Darling-hammond et al., 2020). A well-implemented PBK model will contribute to the implementation of learning and indirectly be able to participate in improving the quality of automotive SMK graduates (Masino \& Nin, 2016; Omar, 2015).

Many advantages obtained by the application of the PBK model are (a) the application of curriculum in automotive vocational schools can collaborate with the needs of the world of work; (b) the competence of graduates following the needs of the industry; (c) learning facilities to keep up with technological developments; and (d) teachers from industry practitioners (Tulsi \& Poonia, 2015).

The implementation of the PBK model on SMK organizers in the automotive field is carried out as a need for the development and improvement of competencies as well as continuous training for automotive teachers. The PBK model is implemented with technical cooperation between vocational education institutions and the automotive industry. PBK model is a training approach for automotive teachers who utilize the automotive industry/workshop to develop experiences and gain competencies that will be able to 
contribute to the social, academic, and career development of learners as well as guidelines for automotive learning activities. (Rochmadi, 2016; Hadromi, 2018).

\section{METHODS}

The development model in this study refers to Richey and Klein's Research and Development model with the research subjects of 75 Automotive Vocational Teachers in Java Island. While the implementation of the model was carried out at Astra Toyota Magelang, Astra Daihatsu Magelang, and Suzuki Ultratune Yogyakarta.

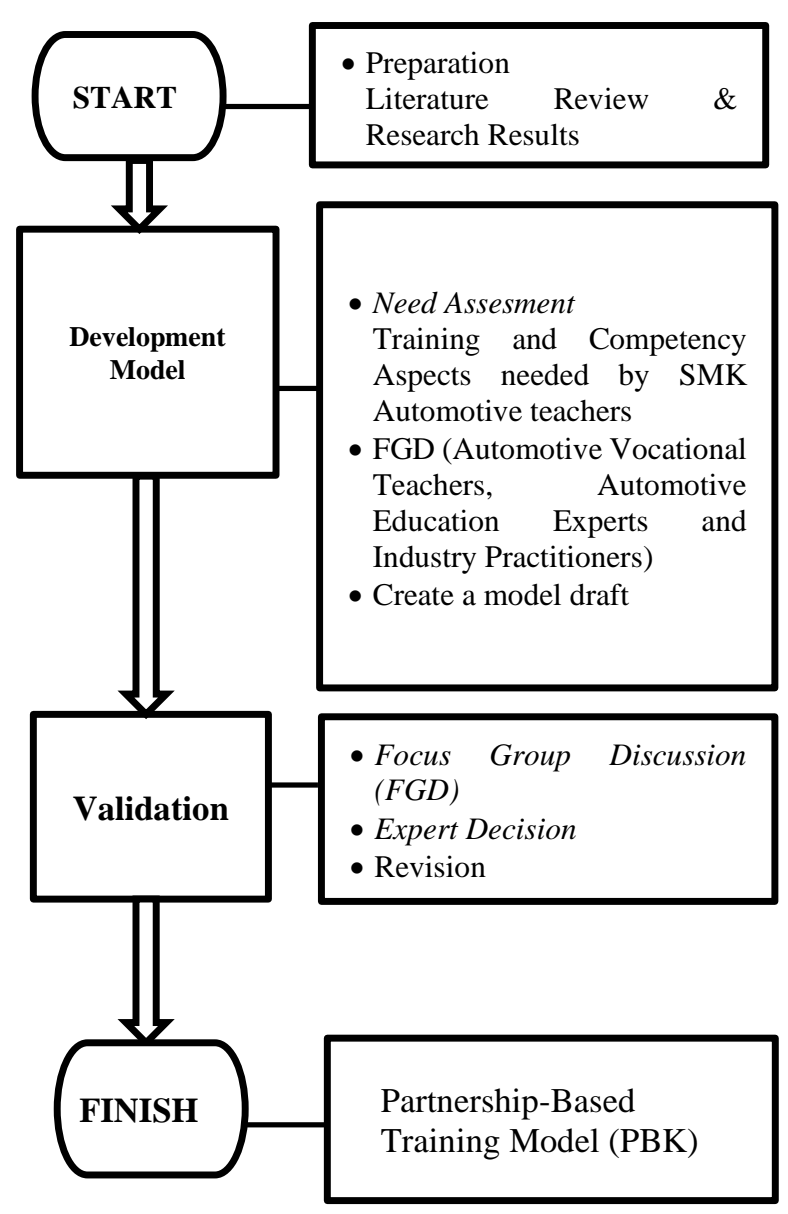

Figure 1. Stages of Research (adapted from Richey and Klein 2009)

Research stages include (1) Model development stage. The model development stage in this research begins with a need assessment that aims to find out information about the needs of educators in improving teaching competencies.

The result of the need assessment in the form of a training model draft. After obtaining the initial draft, a guidebook is then prepared. (2) Validation stage. The validation stage consists of two stages. The first validation phase aims to validate training models and textbooks through Focus Group Discussion (FGD) activities consisting of automotive education experts, vocational education experts, automotive industry extension workers as 
well as SMK automotive skills principals and teachers. The second validation phase aims to measure the success of the model in achieving participants' competencies.

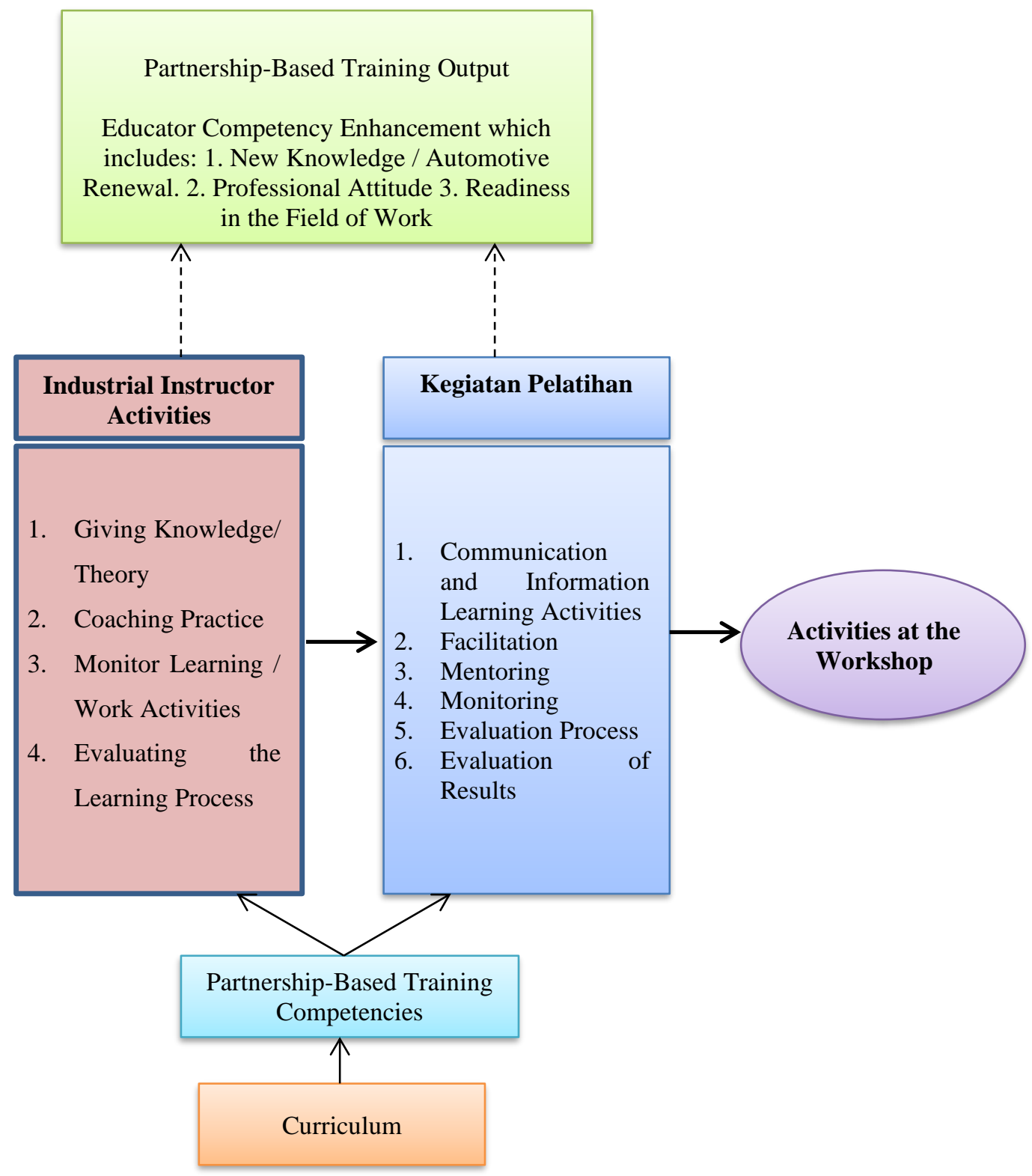

Figure 2. Partnership Based Training Strategy (PBK)

Data collection instruments in this study are interview sheets, questionnaires/questionnaires, and training assessment sheets. Interviews are analyzed qualitatively to find out the needs of educators in improving teaching competencies. The questionnaire is a response questionnaire that aims to find out the teacher's response to the training model implemented. While the training assessment sheet as a measuring instrument for competency achievement. 
Table 1. Criteria for The Definition of Competency Achievement

\begin{tabular}{ccc}
\hline Assessment Norm & Score & Criteria \\
\hline$X \geq \mu+1 . \beta$ & $\mathrm{X} \geq 3,00$ & Very Good (SB) \\
$\mu+1 . \beta>X \geq \mu$ & $3,00>\mathrm{X} \geq 2,50$ & Good (B) \\
$\mu>X \geq \mu-1 . \beta$ & $2,50>\mathrm{X} \geq 2,00$ & Fair (K) \\
$X<\mu-1 \beta$ & $\mathrm{X}<2,00$ & Bad (T) \\
\hline
\end{tabular}

Description:

$\mu$ : average student overall score in one

Class (maximum score + minimum score)

$\beta$ : standard deviation of the overall score (1/6 (maximum score - minimum score))

$\mathrm{X}$ : the score achieved by the student

The response questionnaire in this study used a Likert scale with the category Strongly Agree $(\mathrm{SS})=5$, Agree $(\mathrm{S})=4$, Doubt $(\mathrm{R})=3$, Disagree $(\mathrm{TS})=2$ and Strongly Disagree $(\mathrm{STS})=1$.

Table 2. Questionnaire Response Assessment Criteria

\begin{tabular}{cc}
\hline Formula & Criteria \\
$\boldsymbol{X}>\boldsymbol{\mu}+1,8 \beta$ & Strongly Agree (SS) \\
$\mu+0,6 \beta<\mathrm{X} \leq{ }^{\mu}+1,8 \beta$ & Agree (S) \\
$\mu-0,6 \beta<\mathrm{X} \leq \mu+0,6 \beta$ & Doubt (R) \\
$\mu-1,8 \beta<\mathrm{X} \leq \mu-0,6 \beta$ & Disagree (TS) \\
$\boldsymbol{X} \leq{ }^{\mu}-1,8 \beta$ & Strongly Disagree (STS) \\
\hline
\end{tabular}

(Sugeng Eko Puro Widiyoko, 2009)

\section{RESULTS \& DISCUSSION}

The first activity in need assessment is to conduct interviews with automotive vocational teachers. This activity aims to find out information about the needs of educators in improving teaching competencies. From the stages of need assessment, can be informed that SMK automotive teachers

need to get competency improvement tailored to the needs of the world of work/industry. Furthermore, the competency improvement program of SMK automotive teachers must be implemented and adjusted to the development and demands of the world of work / automotive industry. (Gunadi, 2015) (Wagiran et al., 2019).

After summarizing the results of the need assessment and input experts / automotive education experts, a partnership-based training model (PBK) is produced that is ready to be tested. The PBK model is implemented specifically with the guidance of an industry instructor and is located in a workshop. An image and explanation of the model steps can be seen below.

PBK model for SMK Automotive teachers has components described in table 3. 
Table 3. PBK Model Components

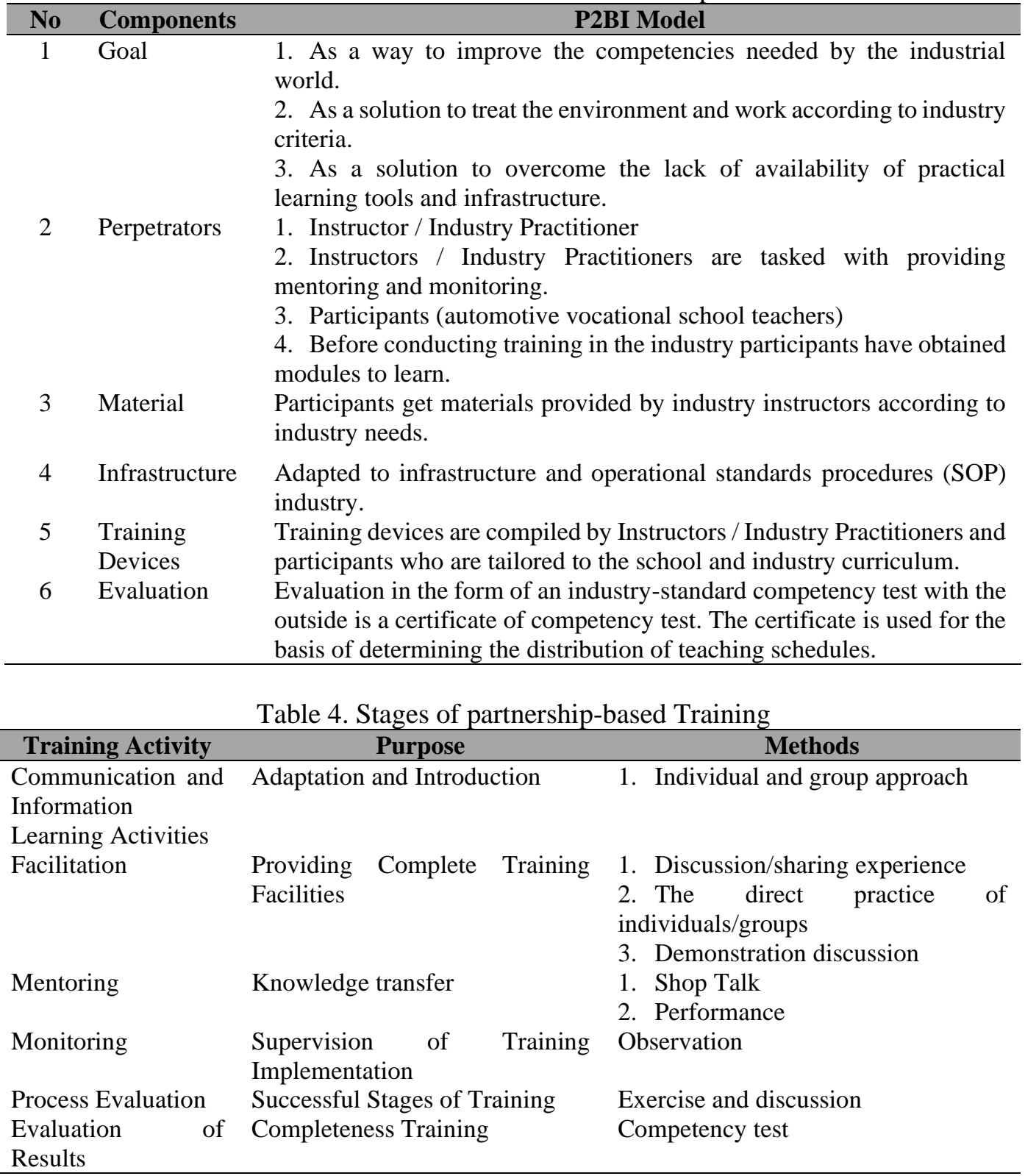

To measure the achievement of the model in producing the expected competencies, the PBK model was tested with 72 automotive vocational school teacher respondents. The measured aspects are attitude, knowledge, and work skills. The attitude is the ability of participants in the preparation, implementation, and evaluation of the end of work without relying entirely on others.

The results of the trial showed that 60 people achieved good criteria and 12 people were very good at achieving competence. Aspects of knowledge showed that 58 people achieved good criteria and 14 people were excellent. While the work skills aspect shows that 63 people achieved good criteria and 9 people were very good 
Table 5. Competency Aspect Comparison Score

\begin{tabular}{lllll}
\multicolumn{1}{c}{ Aspect } & \multicolumn{3}{c}{ Criteria } \\
& \multicolumn{2}{c}{ Very Good } & \multicolumn{1}{c}{ Good } \\
\hline Attitude & 60 persons & $80 \%$ & 12 persons & $20 \%$ \\
Knowledge & 58 persons & $76 \%$ & 14 persons & $24 \%$ \\
Work Skills & 63 persons & $85 \%$ & 9 persons & $15 \%$ \\
\hline
\end{tabular}

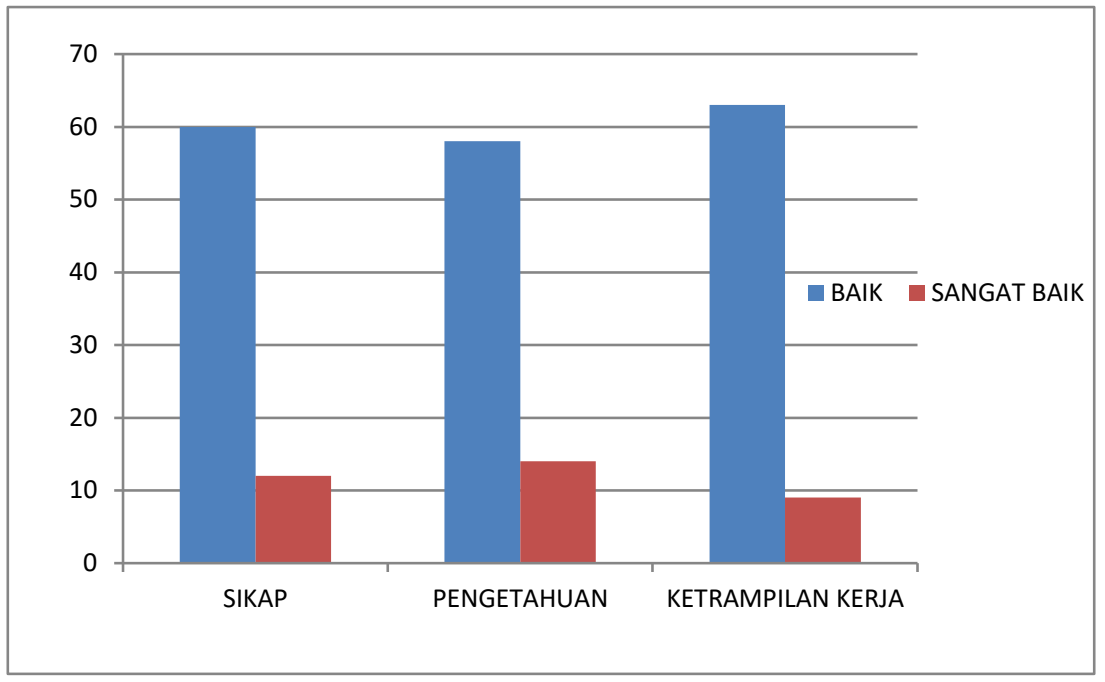

Figure 2. Score Comparison

After applying the PBK model, participants were given a response questionnaire that aims to find out the responses related to the application of the model. The result was an average score on each question in a response poll that showed an average score above 4.83. The average value is that teachers/trainees strongly agree if a partnership-based training model is applied to improve the competence of automotive vocational teachers.

The results of research relevant to the results of the study concluded that the use of partnership-based training approaches in automotive education has a positive effect on competence and sustainable education. (Sudarsono, 2020) (Chiang \& Lee, 2016) (European Centre for the Development of Vocational Training (Cedefop), 2015). Partnership-based training research and evaluation show a correlation between the outside and outer graduates with the learning structure provided by schools and industries as work experience. When program objectives, workplace-based curriculum, and experiences are designed and implemented with adequate staff support and properly evaluated, the program will have a positive impact. (Anjum, 2020) (Suyanto \& Murniati, 2017).

\section{CONCLUSION}

The partnership-based training model is the right alternative model to improve the competence of automotive teachers. Teachers will get real work experience from automotive industry practitioners with a real work environment with 6 model stages, namely: (1) Communication and Information Learning Activities; (2) Facilitation; (3) Assistance; (4) Monitoring; (5) Evaluation Process and (6) Evaluation of Results. The response of automotive participants/teachers with the application of partnership-based training models is very good and strongly agreed to be applied. Partnership-based training models can foster attitude, knowledge, and work skills very well. 


\section{REFERENCES}

Anjum, S. (2020). Impact of internship programs on professional and personal development of business students: A case study from Pakistan. Future Business Journal. https://doi.org/10.1186/s43093-019-0007-3

Audu, R., Abdulkadir, M., \& Kagara, A. B. (2013). Technical vocational education (TVE) institutions and industries partnership: Necessity for graduates skills acquisition. International Journal of Scientific and Research Publications, 3(4), 1-4.

Chiang, C. L., \& Lee, H. (2016). The Effect of Project-Based Learning on Learning Motivation and Problem-Solving Ability of Vocational High School Students. 6(9). https://doi.org/10.7763/IJIET.2016.V6.779

Darling-hammond, L., Flook, L., Cook-harvey, C., Barron, B., Flook, L., Cook-harvey, C., Darling-hammond, L., Flook, L., Cook-harvey, C., \& Barron, B. (2020). Implications for educational practice of the science of learning and development. Applied Developmental Science, 24(2), 97-140. https://doi.org/10.1080/10888691.2018.1537791

European Centre for the Development of Vocational Training (Cedefop). (2015). Vocational pedagogies and benefits for learners: practices and challenges in Europe (Issue 47). Publications Office of the European Union.

Fitriana, Y., \& Sugiyono. (2019). Synchronization of dual system education programs in vocational schools with work. Journal Of Educational Administration Research And Review, 3(2).

Grosch, M. (2017). Developing a competency standard for TVET teacher education in Asean Countries. Jurnal Pendidikan Teknologi dan Kejuruan, 23(3), 279-287. https://doi.org/10.21831/jptk.v23i3.13418

Gunadi. (2015). Peningkatan keterampilan produktif calon guru SMK. Jurnal Pendidikan Dan Teknologi Kejuruan, 21(4), 301-306.

Hadromi. (2018). A model for a vocational school-corporate/industry partnership to improve students' technical skills. World Transactions on Engineering and Technology Education, 16(1), 89-94.

Hrmo, R., Mistina, J., \& Kristofiaková, L. (2016). Improving the quality of technical and vocational education in Slovakia for European labor market needs. International Journal of Engineering Pedagogy (iJEP), 6(2), 14-22.

Iskandar, R., Arifin, Z., \& Sudira, P. (2020). Problems of automotive vocational teachinglearning process for students with mild intellectual disability (MID). International Journal of Advanced Science and Technology, 29(7 Special Issue), 417-424.

Ismail, K., Mohd Nopiah, Z., \& Mohd Sattar, R. (2018). Challenges faced by vocational teachers in public skills training institutions: A reality in Malaysia. Journal of Technical Education and Training, 10(2), 13-27. https://doi.org/10.30880/jtet.2018.10.02.002

Mahendra, S., Soenarto, Sofyan, H., \& Rohmantoro, D. (2019). The teacherpreneur character of vocational high school teacher in Indonesia. International Journal of Recent Technology and Engineering, 8(2), 5877-5880. https://doi.org/10.35940/ijrte.B3786.078219

Masino, S., \& Nin, M. (2016). What works to improve the quality of student learning in developing countries? International Journal of Educational Development, 48, 5365. https://doi.org/10.1016/j.ijedudev.2015.11.012

Muslim, S. (2019). The implementation teaching factory and implications on the preparation of candidates for vocational high school teacher. Humanities \& Social Sciences Reviews, 7(3), 323-330. 
Mustapha, A., Idris, A. M., Kutiriko, A. A., \& Ewugi, A. M. (2016). Competencies needed by automobile technology teachers towards the development of ICT for teachinglearning purposes. CEUR Workshop Proceedings, 1830(November), 11-16.

Nurtanto, M., Sofyan, H., Pardjono, P., \& Suyitno, S. (2020). Development model for competency improvement and national vocational qualification support frames in automotive technology. International Journal of Evaluation and Research in Education, 9(1), 168-176. https://doi.org/10.11591/ijere.v9i1.20447

Omar, M. Z. (2015). The need for in-service training for teachers and it's effectiveness in school the need for in-service training for teachers. International Journal for Innovation Education and Research, 2(11), 1-9.

Rochmadi, S. (2016). Industry partnerships learning models. Jurnal Pendidikan dan Teknologi Kejuruan, 23(1996), 210-225.

Suartini, T. (2019). Influence Application of Learning Model on Vocational Education Based on Quality Insurance. https://doi.org/10.1177/2158244019851552

Sudarsono, B. (2020). Industrial-based practical learning development for teacher competence of automobile technology Industrial-based practical learning development for teacher competence of automobile technology. Journal of Physics: Conference Series PAPER, 1446(1), 1-8. https://doi.org/10.1088/1742$6596 / 1446 / 1 / 012062$

Sudira, P., \& Saputro, S. (2019). Development of vocational high school teachers in Daerah Istimewa Yogyakarta. Global Conferences Series: Sciences and Technology (GCSST), 2, 136-145.

Sugeng Eko Puro Widiyoko. (2009). Evaluasi Program Pembelajaran: Panduan Praktis Bagi Pendidik dan Calon Pendidik. Pustaka Pelajar.

Supriyadi, E., Indro, H. Y., Priyanto, E., \& Surwi, F. (2020). Students' evaluation on teaching in vocational and technical schools. International Journal of Instruction, 13(2), 621-636. https://doi.org/10.29333/iji.2020.13242a

Sutijono. (2016). The contribution of industry to the development of SMK through teacher internship program in the industry. AIP Conference Proceedings, 1778(October 2016). https://doi.org/10.1063/1.4965785

Suyanto, W., \& Murniati, D. E. (2017). The development of students' internship model in Faculty of Engineering Universitas Negeri Yogyakarta. 102(Ictvt), 399-403.

Tulsi, P. K., \& Poonia, M. P. (2015). Expectations of industry from technical graduates: Implications for curriculum and instructional processes. Journal of Engineering Education Transformations, O(0), 19. https://doi.org/10.16920/ijerit/2015/v0i0/59339

Wagiran, Pardjono, Suyanto, W., Herminarto, S., Soenarto, S., \& Yudantoko, A. (2019). Competencies of future vocational teachers: perspective of in-service teachers and educational experts. Cakrawala Pendidikan, 38(2), 387-397. https://doi.org/10.21831/cp.v38i2.25393 